\title{
Examination of the Resilience Levels of Women and Men Do Sport in Gyms
}

\author{
Ali Osman KIVRAK ${ }^{1}$, Mehibe AKANDERE ${ }^{1}$ \\ ${ }^{1}$ Selçuk University, Faculty of Sport Sciences, Konya, Turkey \\ Address Correspondence to AO, Kivrak, e-mail: aokivrak@selcuk.edu.tr
}

\begin{abstract}
The aim of this study is to examine the resilience levels of women and men do sports in gyms. In line with this purpose, it was aimed to compare the resilience levels of men and women do sports in gyms by gender, age, educational status and occupational status variables. A total of 432 members, 229 women and 203 men, participated to the study voluntarily. The short resilience scale used in the study was developed by Smith et al. (2008) and adapted into Turkish by Doğan (2015). Variance and homogeneity of data were tested by using descriptive statistics in capturing of data. In the case of pairwise comparisons, independent sample $t$ test, One-way Anova test in multiple comparisons and Tukey HSD test in determination of source of variance were used Cronbach's Alpha value for this study was set to 78 . While there was no statistical significance observed in the resilience mean values of the members depending on the age, education and profession factors, it was found to be the average value of men members was statistically higher than women members (Table $1, \mathrm{p}<0.05$ ).
\end{abstract}

As a conclusion; the reason why men members have more positive resilience values compared to women members can be explained to be eventuated due to socio-cultural structure, social roles and statuses, and social understanding and privilege given to men.

Key words: Resilience, Women, Sports, Men

\section{INTRODUCTION}

Fraser et al. (17) describe resilience as "the ability to achieve positive and unexpected success under enduring conditions and adjustment to unusual conditions and situations".

In general, resilience is defined as "the adjustment capacity of the individual and sustain the development process against negative experiences"(3).

Resilience is being in harmony with the negative situations caused by the risk event and struggling to reach positive results (23).

Risk is defined as a key factor for the emergence of resilience. Individuals who are not exposed to any traumatic life experiences but who are successful in various fields of life are considered to be successful or competent individuals rather than resilient ones (29).

In the definition of resilience concept, three main points are defined in common. These are; a) risk and/or difficulty, b) positive adjustment, coping, competence and c) protective factors. In this case, resilience is defined as "a phenomenon associated with a healthy adjustment and resulting from the significant interaction of protective factors with existing risk factors that contribute to the adjustment process" Windle (44).

In this case, "high risk" environments or conditions addressed in resilience researches and have significant negative impacts on individuals and individuals who demonstrate a healthy adjustment under "high risk" conditions should be clearly defined. Risk refers to difficulty, distress or disaster (adversity) and is a statistical concept. In general, the risk is used to identify specific groups instead of individuals. Risk factors are defined as "effects that will increase the likelihood of emergence of a negative situation or cause a potential problem to persist" Kirby and Fraser (26).

Resilience is not a personality characteristic that protects the individual from the negative effects of the environment. The real reasons that lead the individual to success are protective factors such as individuals' having attitudes and skills to reduce the impact of environmental risk factors Beauvais and Qetting (7) psychosocial resources that are associated with competence Caffo and Belaise (9). 
Psychologically resilient children and adolescents are considered as happier individuals Kumpfer (28), and their sense of humor and are at the highest level (33). In addition, resilient children and adolescents have been found to be healthier, have fewer childhood diseases, physically stronger, and having more regular sleep and eating patterns $(28,30)$.

In The gaining recognition of children or adolescents from their peers and being supported by their peers are also important environmental factors that influence resilience Werner and Smith (42), Criss et al. (11) and most of the adolescents who were known to have resilience were friends and confidants among their peers (34).

For this reason, the fact that the factors or conditions that affect psychological strength are formed within the family, school, environment and society as well as the individual's own personality or internal features constitute a sense that this concept can be discussed and understood from the ecological perspective $(16,19)$. Therefore, from perspective of an ecological approach, it may not be the right approach to assume that all the individual and environmental protective factors (or risk factors) mentioned are the reasons for the resilience of children or adolescents alone and directly (16).

The sport, which dates back to centuries, has become a significant part of social life since its emergence. As well as provides making use of leisure time, self-confidence,socializing and solidarity, the sport concept has gained a different meaning with researching and revealing its role in development of physical and mental health of individuals $(2,27)$.

Sports and physical activities as protective factors in the development of resilience were investigated and tried to be revealed in resilience studies as factors that have impacts on the development of resilience, and these factors were determined as "protective factors". Benard (8) mentioned four factors related to resilience, social competence, problem solving skills, autonomy, purpose and future perception. Masten and Coastworth (32) emphasized the importance of selfregulation and self-control skills.

Whitehead et al. (43) stated that sports and physical activities can affect the physical self-esteem as in a positive manner as a protective factor in the development of resilience and can increase the motivation of the individual.

The aim of this study is to examine the resilience levels of women and men do sports in gyms.

\section{MATERIAL AND METHOD}

\section{Research Model}

The research was supported in a descriptive screening model. The screening model is a research approach that aims to describe a situation that exists in the past or the present as it is (25). One of the most important features of the surveys figured in the screening model is the high level of validity due to the collection of the data of this type of research from different sources, having detailed information on the subject researched and collecting the data from great number of individuals (24).

\section{Research Group}

The sample group of the study consisted of 432 volunteer members, 229 women and 203 men members subscribed in gyms in Konya province.

\section{Data Collection Tools}

The datawere obtained within scope of the study by using the "Personal Information Form" and "Resilience Scale".

\section{Personal Information Form}

This form is designed to provide information about the gender, age, educational status and occupational status of the individuals who constitute the research group.

\section{Short Resilience Scale (SRS)}

SRS was developed in order to measure individuals' potentials of pulling themselves together and their resilience level. The scale was developed by Smith et al. (39) and adapted to Turkish by Doğan (12). This 5-point Likert-type scale consists of 6 items is a measurement tool in form of self-statement. It is planned as "not appropriate at all" (1), "not appropriate" (2), "slightly appropriate" (3), "appropriate" (4) and "completely appropriate" (5). The articles 2, 4 and 6 of these 6 items are coded in reverse but must be translated in the scoring key in the first place. The high scores obtained after this procedure show high levels of resilience and low scores show low levels of resilience. An exploratory factor analysis has been carried out in order to determine what kind of the structure of the 
university students exhibit in Turkey. As a result of the analysis, a single factor structure was obtained which explained $54 \%$ of the total variance. These results prove that PSÖ-K is sufficiently valid (1).

\section{RESULTS}

\section{Statistical Analysis}

SPSS 25 package program was used to analyze the data. By using descriptive statistics of the obtained data, variance and homogeneity of data were tested. In the case of pairwise comparisons, independent sample $\mathrm{t}$ test, One-way anova test in multiple comparisons and Tukey HSD test in determination of source of variance were used Cronbach's Alpha value for this study was set to 78 .

Table 1. Resilience changes by gender factor

\begin{tabular}{cccccccc}
\hline Gender & $\mathbf{N}$ & $\overline{\mathbf{x}}$ & Ss & Min & Maks & t & p \\
\hline Women & 229 & 18.76 & 4.23 & 6.00 & 30.00 & \multirow{2}{*}{-4.251} & \multirow{2}{*}{$.000^{*}$} \\
\hline Men & 203 & 20.33 & 3.33 & 12.00 & 29.00 & & \\
\hline Total & 432 & 19.50 & 3.91 & 6.00 & 30.00 & \\
\hline
\end{tabular}

Significant difference between groups $(p<0.05)$.

When Table 1 is examined, it was found that the resilience mean values of men members $(20.33 \pm 3.33)$ were statistically higher than Women members $(18.76 \pm 4.23) \quad(\mathrm{p}<0.05)$.

Table 2. Resilience changes by age factor

\begin{tabular}{|c|c|c|c|c|c|c|c|}
\hline Age & $\mathbf{N}$ & $\overline{\mathbf{x}}$ & Ss & Min & Maks & $\mathbf{F}$ & $\mathrm{p}$ \\
\hline $15-18$ years old & 25 & 19.96 & 3.46 & 13.00 & 26.00 & \multirow{4}{*}{.216} & \multirow{4}{*}{.885} \\
\hline 19-22 years old & 62 & 19.71 & 3.82 & 6.00 & 29.00 & & \\
\hline 23-26 years old & 118 & 19.44 & 3.74 & 10.00 & 29.00 & & \\
\hline 27 and older & 227 & 19.42 & 4.08 & 6.00 & 30.00 & & \\
\hline
\end{tabular}

As can be seen in Table 2, there was no statistically significant difference between the mean values of resilience changes depending on age factor.

Table 3. Resilience changes by education factor

\begin{tabular}{|c|c|c|c|c|c|c|c|}
\hline Education: & $\mathbf{N}$ & $\bar{x}$ & Ss & Min & Maks & $\mathbf{F}$ & $\mathrm{p}$ \\
\hline Elementary-secondary school & 28 & 19.00 & 3.23 & 11.00 & 28.00 & \multirow{4}{*}{1.631} & \multirow{4}{*}{.181} \\
\hline High school & 115 & 18.91 & 3.85 & 6.00 & 27.00 & & \\
\hline Undergraduate & 241 & 19.72 & 4.03 & 6.00 & 30.00 & & \\
\hline Postgraduate & 48 & 20.08 & 3.65 & 13.00 & 27.00 & & \\
\hline
\end{tabular}

When Table 3 is examined, no statistical change in psychological resilience mean values was determined due to education factor.

Table 4. Resilience changes by occupation factor

\begin{tabular}{|c|c|c|c|c|c|c|c|}
\hline Occupation & $\mathbf{N}$ & $\bar{x}$ & Ss & Min & Maks & $\mathbf{F}$ & $\mathrm{p}$ \\
\hline Unemployed & 185 & 19.50 & 3.58 & 6.00 & 29.00 & \multirow{4}{*}{.530} & \multirow{4}{*}{.662} \\
\hline Government officer & 92 & 19.89 & 4.32 & 10.00 & 30.00 & & \\
\hline Private sector & 117 & 19.21 & 3.79 & 6.00 & 27.00 & & \\
\hline Self-employed & 38 & 19.45 & 4.72 & 10.00 & 29.00 & & \\
\hline
\end{tabular}

As can be seen in Table 4, there was no statistically significant difference between the mean values of resilience changes depending on occupation factor.

\section{DISCUSSION}

The aim of this study is to examine the resilience levels of women and men do sports in gyms. In line with this purpose, it was aimed to compare the resilience levels of men and women do sports in gyms by gender, age, educational status and occupational status variables.

In this study, it was found that the resilience mean values of men members $(20.33 \pm 3.33)$ were statistically higher than women members (18.76 \pm 4.23) $(\mathrm{p}<0.05)$. Aslan (4) reported that, according to 
the research carried out on university students, resilience levels were statistically differentiated according to their gender and the resilience levels of the men participants was higher than the women participants $(p<0.05)$. Similarly, Erdoğan (14), in his study carried out on university students, found that men students had high resilience levels compared to women students. In a similar study carried out by Bahadir (6), it was aimed to examine the resilience levels of the students studying in health-related faculties of universities (dentistry, pharmacy, health sciences faculties and medical faculties) according to some demographic variables. And it was reported that level of resilience of men students found to be higher when it is considered in respect of gender factor. In a study carried out by Sezgin (38) it was reported that the level of resilience in university students was high in favor of men students. These values are similar to our study.

However, the results related to the gender variable differ in the studies related to resilience.

In studies of Gündaş and Koçak (20) and Oktan (35) it was reported that women's resilience level was higher than men's resilience level. Oktan et al. (36) reported that the level of resilience was high in favor of women students in the study conducted on the faculty of education students. Gender seems to be is associated with resilience and it is stated that the resilience of girls is higher in children at risk (28). The results of this study differ from our study.

Aydoğdu (5), Gürgan (22), Özcan (37), Tösten (40) concluded that the resilience levels of men and women did not differ significantly. In the study conducted by Eryilmaz (15), it was reported that resilience levels of university students did not show a significant difference according to their gender.

In these years when university students are prepared for life and profession, they are expected to be individuals who are able to cope with their problems, have active participation, able to communicate positively, aware of the factors that protect internal and environmental psychological health and can use them for their purposes (22).

In this study, there was no statistically significant difference between the mean values of resilience changes depending on age factor $(p>0,05)$. Aslan (4) reported in his study carried out on university students, reported that the level of resilience of the participants was not statistically different according to age groups ( $p>0.05)$. In the research carried out by Gündüz Algünerhan (21) it was reported that the age group variable does not have significant effect on the resilience. In the study conducted by Eryllmaz (15) on the university it was found that the age factor does not cause any change in resilience changes, and these values are similar to our research results.

Individuals with a high level of resilience can easily cope with the negative situations and events they encounter in their lives and can overcome these problems very easily (41).

In our study, no statistical change in psychological resilience mean values was determined due to education factor $(p>0,05)$. Elif Selçuklu (13) reported that there was no difference between the resilience and education level of teachers in a study conducted on the resilience of pre-school teachers. These values are similar to our study.

In our study, there was no statistically significant difference between the mean values of resilience changes depending on profession factor $(\mathrm{p}>0,05)$.

Gilligan (18) stated that sport activities are very important as well as social and cultural activities in the development of resilience in young people.

Martinek and Hellison (31) stated that physical activities and sport is a very suitable tool for improving the resilience of young people and that they improve their social competence and autonomy and instill hope and optimism in them.

In addition to the direct effect of sport and physical activity on the development of resilience, there is also an important role in the development of the above-mentioned protective factors. It is stated that physical health plays an important role in terms of the individual's ability to cope with and overcome stressful experiences and that being unhealthy is an important risk factor (10).

Sports and physical activity serve as an important tool in the development of the resilience of the individual. Sports appeal to individuals of all ages. On the other hand, stress affects individuals of all ages and jeopardizes the harmony of the individual. In particular, it may be advisable to organize physical activity programs for individuals living under intense stress and to encourage them to participate in sports. The effect of the programs prepared in this way on the development of 
resilience can be demonstrated by experimental studies.

Resilience development projects can be organized for children, young people and adults at risk, and the impact of participation in sports can be tested by directing them to sports branches appropriate for their abilities.

\section{REFERENCES}

1. Açıkgöz M. Çukurova üniversitesi tıp fakültesi öğrencilerinin psikolojik sağlamlık ile mizah tarzları ve mutluluk düzeyi arasındaki ilişkinin incelenmesi. Yayınlanmamış yüksek lisans tezi. Çă̆ Üniversitesi Sosyal Bilimler Enstitüsü, Mersin. 2016.

2. Arslan C, Güllü M, Tutal V. Spor yapan ve yapmayan ilköğretim öğrencilerinin depresyon durumlarının bazı değişkenlere göre incelenmesi. Niğde Üniversitesi, Beden Eğitimi ve Spor Bilimleri Dergisi, 2011; 5(2): 120-132.

3. Arslan G. Çocuk ve genç psikolojik sağlamlık ölçeği'nin (ÇGPSÖ-12) psikometrik özellikleri: Geçerlilik ve güvenirlik çalışması. Ege Eğitim Dergisi, 2015; 16(1): 1-12.

4. Aslan E. Üniversite öğrencilerinde psikolojik sağlamlık düzeyinin kişinin mizaç özellikleri, çocukluk dönemi travma durumları, ebeveyn tutumları ve demografik özelliklerine göre incelenmesi. Yakın Doğu Üniversitesi, Sosyal Bilimler Enstitüsü, Yüksek Lisans Tezi, Lefkoşa. 2018.

5. Aydoğdu T. Bağlanma stilleri, başa çıkma stratejileri ile psikolojik dayanıklılık arasındaki ilişkinin incelenmesi. Yayınlanmamış Yüksek Lisans Tezi. Gazi Üniversitesi, Gazi Eğitim Bilimleri Enstitüsü, Ankara.2013.

6. Bahadır E. Sağlıkla ilgili fakültelerde eğitime başlayan öğrencilerin psikolojik sağlamlık düzeyleri. Yayınlanmamış Yüksek Lisans Tezi. Hacettepe Üniversitesi, Sağlık Bilimleri Enstitüsü, Ankara. 2009.

7. Beauvais F, Qetting ER. Drug use, resilience, and the myth of the golden child. (Ed: M.D. Glantz \& J. L. Johnson) Resilience and development: Positive life adaptations. New York:Kluwer Academic/Plenum Published, 1999.

8. Benard B. Fostering resiliency in kids" Http://Hopeworks.Org/ Formation / Documents / Fostering resiliency. Pdf, 20.03.2010 tarihinde erişildi. 1991.

9. Caffo E, Belaise C. Psychological aspects of traumatic injury in children and adolescents. Child and Adolescent Psychiatric Clinics of North America, 2003; 12: 493-535.

10. Coleman J, Hagell A. The nature of risk and resilience. In. Coleman J., \& Hagell, A. (Eds.), Adolescence, risk and resilience: Against The Odds, 2007, 1-17.

11. Criss MM, Pettit GS, Bates JE, Dodge KA, Lapp AL. Family adversity, positive peer relationship, and children's externalizing behavior: A Longitudinal Perspective on risk and resilience. Child Development, 2002, 73: 1220-1237.

12. Doğan T. Kısa psikolojik sağlamlık ölçeği'nin türkçe uyarlaması: Geçerlik ve güvenirlik çalışması. The Journal of Happiness \& Well-Being, 2015, 3(1): 93-102.

13. Elif Selçuklu A. Örgütsel bağlılığın bir yordayıcısı olarak kurum kültürü ve psikolojik dayanıklılık: Okul öncesi öğretmenler üzerine bir araştırma: Yayımlanmamış Yüksek Lisans Tezi. Erciyes Üniversitesi, EBE, Kayseri. 2013.
14. Erdoğan E. Tanrı algısı, dini yönelim biçimleri ve öznel dindarlığın psikolojik dayanıklılıkla ilişkisi: Üniversite örneklemi. Mustafa Kemal Üniversitesi, Sosyal Bilimler Enstitüsü Dergisi, 2015, 12(29): 223-246 .

15. Eryılmaz S. Üniversite öğrencilerinde psikolojik sağlamlığı yordamada yaşam doyumu, benlik saygısı, iyimserlik ve kontrol odağının incelenmesi. Muğla Üniversitesi, Eğitim Bilimleri Enstitüsü, Yayınlanmamış Yüksek Lisans Tezi, Muğla. 2012.

16. Fraser M. Risk and resilience in childhood: An Ecological Perspective. Washington, Dc: Nasw Pres, 1997.

17. Fraser MW, Richman JM, Galinsky, MJ. Risk, protection and resilience: Toward A Conceptual Framework For Social Work Practice. Social Work Research, 1999; 23: 129-208.

18. Gilligan R. Enhancing the resilience of children and young people in public care by mentoring their talents and interests. Child and Family Social Work, 1999; 4: 187-196.

19. Greene R. Human behavior theory: A Resilience Orientation. (Ed: R. Greene) Resiliency: An İntegrated Approach To Practice, Policy, And Research. Washington, Dc: Nasw Pres, 2002.

20. Gündaş A, Koçak R. Lise öğrencilerinde psikolojik sağlamlığın yordayıcısı olarak benlik kurgusu. Uluslararası Sosyal Araştırmalar Dergisi, 2015; 8(41): 795-802.

21. Gündüz Algünerhan R. 12-14 yaşındaki ergenlerde algılanan anne baba tutumları benlik algısı ve psikolojik sağlamlık. Nişantaşı Üniversitesi, Sosyal Bilimler Enstitüsü, İstanbul. 2017.

22. Gürgan U. Üniversite öğrencilerinin yılmazlık ve iyilik halinin bazı değişkenlere göre incelenmesi. E-Journal Of New World Sciences Academy, 2014. Http://Dx.Doi.Org/10.12739/Nwsa. 2014.9.1.1c0603.

23. Karaırmak Ö, Siviş-Çetinkaya R. Benlik saygısının ve denetim odağının psikolojik sağlamlık üzerine etkisi: Duyguların aracı rolü. Türk Psikolojik Danışma ve Rehberlik Dergisi, 2011, 4(35): 30-43.

24. Karakaya İ. Bilimsel araştırma yöntemleri. A. Tanrı̈̈̆gen. (Edt.). Bilimsel araştırma yöntemleri, 2011.

25. Karasar N. Bilimsel araştırma yöntemi. Seçkin Yayıncılık, Ankara. 2014.

26. Kirby LD, Fraser, MW. Risk and resilience in childhood. (Ed: M. Fraser) Risk and resilience in childhood. Washington, Dc: Nasw Pres, 1997.

27. Koruç Z, Bayar P. Egzersizin depresyon tedavisindeki yeri ve etkileri. Hacettepe J. of Sport Sciences, 2004; 15(1): 49-64.

28. Kumpfer KL. Factors and processes contributing to resilience: The Resilience Framework. (Ed: M. D. Glantz \& J. L. Johnson) Resilience And Development: Positive Life Adaptations. New York: Kluwer Academic/Plenum Publishers, 1999.

29. Luthar S, Cicchetti D. Theconstruct of Resilience: Implications for interventions and social policies. Development and Psychopathology, 2000; 12: 857-885.

30. Mandleco BL, Peery JC. An organizational framework for conceptualizing resilience in children. Journal of Child and Adolescent Psychiatric Nursing, 2000; 13(3): 99-111.

31. Martinek TJ, Hellison DR. Fostering Resiliency in Undeserved Youth Through Physical Activity. Quest, 1997; 49: 34-49.

32. Masten AS, Coastworth JD. The development of competence in favorable and unfavorable environments: Lessons from research on successful children. American Psychologist, 1998; 53(2): 205-220. 
33. Masten AS. Humor and competence in school-aged children. Child Development, 1986; 57: 461-473.

34. McWhirter JJ, McWhirter BT, McWhirter AM, McWhirter EH. At-Risk Youth: A Comprehensive Response For Counselors, Teachers, Psychologists, and Human Service Professionals. Pasific Groove, Usa: Brooks/Cole Publishing Company, 1998.

35. Oktan V. Üniversite sınavına hazırlanan ergenlerin psikolojik sağlamlıklarının çeşitli değişkenlere göre incelenmesi. Yayımlanmamış doktora tezi. Karadeniz Teknik Üniversitesi, Trabzon. 2008

36. Oktan V, Odacı H, Çelik ÇB. Psikolojik doğum sırasının psikolojik sağlamlığın yordanmasındaki rolünün incelenmesi. Abant İzzet Baysal Üniversitesi, Eğitim Fakültesi Dergisi, 2014; 1-13.

37. Özcan B. Anne-babaları boşanmış ve anne-babaları birlikte olan lise öğrencilerinin yılmazlık özellikleri ve koruyucu faktörler karşılaştırılması. Yayınlanmamış Yüksek Lisans Tezi, Ankara Üniversitesi, Eğitim Bilimleri Enstitüsü, Ankara. 2005.

38. Sezgin K. Üniversite öğrencilerinin psikolojik sağlamlık ve dindarlık düzeylerinin incelenmesi (Dicle Üniversitesi Örneği). Yayımlanmamış Yüksek Lisans Tezi, Dicle Üniversitesi, Sosyal Bilimler Enstitüsü, Diyarbakır. 2016.

39. Smith BW, Dalen J, Wiggins K, Tooley E, Christopher P, Jennifer Bernard J. The brief resilience scale: Assessing the ability to bounce back. International Journal of Behavioral Medicine, 2008; 15: 194-200.

40. Tösten R. Öğretmenlerin pozitif psikolojik sermayelerine ilişkin algılarının incelenmesi. Yayınlanmamış Doktora Tezi, Gaziantep Üniversitesi, Eğitim Bilimleri Enstitüsü, Gaziantep. 2015.

41. Ülker Tümlü G, Recepoğlu E. Üniversite akademik personelinin psikolojik dayanıklılık ve yaşam doyumu arasındaki ilişki. Yükseköğretim ve Bilim Dergisi, 2013; 3(3): 205-213.

42. Werner EE, Smith RS. Overcoming The Odds: High Risk Children From Birth To Adulthood. Ithaca, Ny: Cornell University Pres, 1992.

43. Whitehead JR, Corbin CB, Fox KR. Self-Esteem in children and youth: The role of sport and physical education. In Fox, K. R. (Ed) The physical self: From motivation to well-being (pp. 175-203) Champaign, IL, Us: Human Kinetics Publishers, 1997.

44. Windle M. Critical conceptual and measurement issues in the study of resilience. (Ed: Glantz, M. D.\& Johnson, J. L.) Resilience and Development: Positive Life Adaptations. New York: Kluwer Academic/Plenum Publishers, 1999. 